\title{
Residual effect of nitrogen fertilizers formulated with biochar
}

\begin{abstract}
Biochar-based nitrogen fertilizers provide productivity and efficiency of nitrogen use gains, but knowledge is scarce about the residual effect for subsequent crops. We evaluated the residual effect of biochar-based nitrogen fertilizers formulated with urea and charcoal fines residues from the coal manufacturing process for the supply of the Brazilian steel park. The treatments tested were related to the residual effect of $80 \mathrm{~kg} \mathrm{Nha}^{-1}$ applied via side dressing in an experiment with corn cultivation under field conditions. After corn harvesting, soil samples from the $0-15 \mathrm{~cm}$ layer were collected from each experimental plot, respecting the treatments represented by the following sources of $\mathrm{N}$, besides the control: ammonium nitrate, urea and three biochar-based fertilizers $\mathrm{r}\left(\mathrm{F}_{51 / 10}, \mathrm{~F}_{40 / 17}\right.$, and $\left.\mathrm{F}_{29 / 20}\right)$. The soil was placed in pots (3L) and fertilized with macronutrients (except $\mathrm{N}$ ) and micronutrients. The test plant was black oats (Avena strigosa Schreb) and three shoot cuts of the plants were performed during 84 days of experimentation. The initial levels of inorganic $\mathrm{N}$ in soil, dry mass produced (shoot and root) and $\mathrm{N}$ content absorbed by black oats were analyzed.
\end{abstract}

The initial concentrations of inorganic $\mathrm{N}$ in the soil were similar among nitrogen sources. Some highlight is the higher $\mathrm{NO}_{3}^{-}$concentration for ammonium nitrate, as a result of the low efficiency of $\mathrm{N}$ use by corn in the field stage. Plant dry mass and $\mathrm{N}$ content confirmed the greatest residual effect for ammonium nitrate, for the above reason, combined with zero loss of $\mathrm{NH}_{3}$ in the field. The residual effect of $\mathrm{F}_{51 / 10}$ (biochar-based nitrogen fertilizer with $51 \%$ biochar and $10 \% \mathrm{~N}$ ) was higher than that observed for urea when considering the $\mathrm{N}$ content absorbed by oats. The superiority of the $\mathrm{F}_{51 / 10}$ was credited to the slower $\mathrm{N}$ release of this fertilizer, as the losses of $\mathrm{NH} 3$ from biochar-based fertilizers were as large or greater than determined for urea.

Biochar-based nitrogen fertilizer formulated with urea has a longer residual effect compared to the exclusive application of urea and this effect is related to the slow $\mathrm{N}$ release, which demonstrates the potential of this technology in the formulation of enhanced-efficiency $\mathrm{N}$ fertilizers.

Keywords: biochar-based fertilizer, urea, black oat, enhanced-efficiency fertilizer
Volume 3 Issue 6 - 2019

\author{
Thaís Alves de Carvalho, ' Aline Peregrina \\ Puga, ${ }^{2}$ Adriana Marlene Moreno Pires, ${ }^{3}$ \\ Marcos Antônio Vieira Ligo, ${ }^{3}$ Cristiano \\ Alberto de Andrade 4 \\ IStudent of Chemical Processes, College of Technology of \\ Campinas, Brazil \\ ${ }^{2}$ Fapesp Scholarship, Postdoctoral student at Embrapa, Embrapa \\ Enviroment Unit, Brazil \\ ${ }^{3}$ Brazilian Agricultural Research Corporation (Embrapa), \\ Embrapa Environment Unit, Brazil \\ ${ }^{4}$ Brazilian Agricultural Research Corporation (Embrapa), \\ Embrapa Environment Unit, Brazil
}

Correspondence: Cristiano Alberto de Andrade, Embrapa Environment, Rodovia SP-340, Km 127,5; Tanquinho Velho CEP: |39|8-| | 0, Jaguariúna, Estado de São Paulo, Brazil,

Email cristiano.andrad@embrapa.br

Received: December 19, 2019 | Published: December 27, 2019

\section{Introduction}

Adequate nutrient supply to crops without excess, reducing risk of contamination, is one of the cornerstones of competitive and sustainable agriculture. In this sense, $\mathrm{N}$ has special emphasis due to the amounts absorbed by crops ${ }^{1,2}$ and due to the environmental risks associated with the reactive forms of $\mathrm{N}$ in the environment. ${ }^{3}$

The nitrogen use efficiency (NUE) by crops is globally low, around $30-40 \%,{ }^{4}$ which restricts sustainable intensification of agriculture. The complexity of soil $\mathrm{N}$ transformations and various loss routes, in fact, pose challenges for plant nutrition and environmental commitments. ${ }^{3}$

Improvements in management practices, such as application rate adjustment and splitting nitrogen application increase NUE by plants. ${ }^{2,5}$ Other alternatives more related to fertilizer technology can also be used, for example, products with slow release of $\mathrm{N}$, reducing the risk of loss. Such technologies are relatively high cost, making it difficult for farmers to adopt them.

Biochar-based nitrogen fertilizers ${ }^{6}$ or direct application of biochar to the soil can increase the NUE. ${ }^{7,8}$ The biochar is produced by pyrolysis of any biomass, where there is thermal decomposition of the material in environment with low concentration or absence of $\mathrm{O}_{2}{ }^{9}$ Biomass as a raw material for pyrolysis may range from since from animal and vegetable, up until to synthetic organic compounds (synthetic rubber, for example). ${ }^{9-11}$

Pyrolysis process has the potential for application in different situations, such as recycling a large amount of agricultural and forest waste, ${ }^{12}$ reducing contamination associated with improper disposal in the environment. The conversion of waste into $\mathrm{BC}$ also promotes the elimination of active pathogens in animal waste and in sewage sludge. ${ }^{13}$

Biochar production exclusively to agricultural use, aiming the improve of efficiency fertilizers could result in costs which are prohibitive. Charcoal produced to supply Brazilian steel park generates fine coal, which could be used for this purpose, reducing the cost of the final product. Approximately ten million tons of charcoal vegetal are produced per year. ${ }^{14} \mathrm{Coal}$ fines represent $15 \%$ of this total, and just part is reused in the steel industry.

Biochar based fertilizers provided 15 to $30 \%$ increments in rice productivity, with an $\mathrm{N}$ use efficiency value in the order of $80 \%,{ }^{15}$ reminding that world average is $40 \%{ }^{4}$ 
BC effect on NUE increase is at least partially related to surface charge phenomena, ${ }^{7}$ which justifies $\mathrm{BC}$ use in the field as a soil conditioner and to increase NUE of conventional nitrogen sources. Steiner et al. ${ }^{8}$ verified at sorghum culture that NUE was $18 \%$ higher in the NPK and BC plots comparatively with the parcels that received only NPK.

$\mathrm{N}$ release of increased efficiency fertilizers are more synchronized with crop development and they can eventually result in greater residual effect for later crops $^{16}$ since losses are reduced. We evaluated the residual effect of biochar-based nitrogen fertilizers formulated with urea and charcoal fines residues from the coal manufacturing process for the supply of the Brazilian steel park.

\section{Material and methods}

Residual effect evaluation of biochar-based fertilizers was carried out under greenhouse conditions. Samples of an Oxisol, of clayey texture, were collected after corn harvesting in a field experiment conducted in the 2017/2018 crop. $^{17}$ Corn was cultivated and the following nitrogenous sources were used $\left(80 \mathrm{~kg} \mathrm{ha}^{-1}\right)$, besides control treatment (without $\mathrm{N}$ ): ammonium nitrate, urea, and three formulations based on biochar $\left(\mathrm{F}_{51 / 10}, \mathrm{~F}_{40 / 17}\right.$, and $\left.\mathrm{F}_{29 / 20}\right)$. Total nitrogen and carbon contents of the fertilizers were determined using an elemental analyzer (TruSpec; LECO, St. Joseph, MI) and the results are shown in Table 1.

Table I Nitrogen and carbon concentrations in fertilizers

\begin{tabular}{llll}
\hline Fertilizer & Biochar\% & $\mathbf{N} \%$ & $\mathbf{C} \%$ \\
\hline $\begin{array}{l}\text { Ammonium nitrate } \\
(\mathrm{AN})\end{array}$ & - & $29 \pm 0,3$ & $\mathrm{BDL}(2)$ \\
Urea (U) & - & $46 \pm 0, \mathrm{I}$ & $18 \pm 0,2$ \\
$\mathrm{~F}_{51 / 10}$ & $5 \mathrm{I}$ & $10 \pm 0, \mathrm{I}$ & $47 \pm 12,9$ \\
$\mathrm{~F}_{40 / 17}$ & 40 & $17 \pm 0,1$ & $41 \pm 10,9$ \\
$\mathrm{~F}_{29 / 20}$ & 29 & $20 \pm 0,5$ & $37 \pm 8,5$ \\
\hline
\end{tabular}

'Biochar-based fertilizers formulated with urea, 22\% of bentonite and $5 \%$ pregelatinized maize flour. Subscript numbers separated by bar indicate the biochar / nitrogen ratio.

${ }^{2} \mathrm{BDL}$ means below detection limit.

After corn harvesting on April 25, 2018, we collected 10 simple soil samples (layer 0-15 cm) side dressing in the three central lines of each plot, obtaining a representative sample of each treatment. The samples were homogenized, air-dried and sieved ( $2 \mathrm{~mm}$ mesh) for later use in the greenhouse experiment for residual effect evaluation. In these samples contents of ammonium $\left(\mathrm{NH}_{4}^{+}\right)$, nitrate $\left(\mathrm{NO}_{3}^{-}\right)$and ammonium + nitrate (inorganic $\mathrm{N}=\mathrm{NH}_{4}^{+}+\mathrm{NO}_{3}^{-}$) - extraction with 2 mol L-1 $\mathrm{KCl}$ solution and flow injection analysis (FIA) in equipment model QUIKCHEM 8500 (LACHAT) ${ }^{18,19}$ - were determined.

Samples of two kilograms of soil were placed to polyethylene pots (3L). Planting fertilization was applied via solution with the following nutrient concentrations: $250 \mathrm{mgkg}^{-1}$ of P; $140 \mathrm{mg} \mathrm{kg}^{-1}$ of K; $80 \mathrm{mgkg}$ ${ }^{1}$ of $\mathrm{Mg} ; 59 \mathrm{mg} \mathrm{kg}^{-1}$ of $\mathrm{S} ; 161 \mathrm{mg} \mathrm{kg}^{-1}$ of Ca; $2,2 \mathrm{mgkg}^{-1}$ of Mn; 1,9 $\mathrm{mgkg}^{-1}$ of Cu; $2,0 \mathrm{mg} \mathrm{kg}^{-1}$ of Zn; $0,7 \mathrm{mg} \mathrm{kg}^{-1}$ of B. as Nutrient saltsused were: $\mathrm{K}_{2} \mathrm{HPO}_{4}, \mathrm{KCl}, \mathrm{CaHPO}_{4}, \mathrm{MgSO}_{4}, \mathrm{ZnSO}_{4} .7 \mathrm{H}_{2} \mathrm{O}, \mathrm{MnSO}_{4} \cdot \mathrm{H}_{2} \mathrm{O}$, $\mathrm{CuSO}_{4} .5 \mathrm{H}_{2} \mathrm{O}$ and $\mathrm{H}_{3} \mathrm{BO}_{3}$. The side dressing was performed 15 days after planting via solution providing $160 \mathrm{mg} \mathrm{kg}^{-1} \mathrm{P}$ and $127 \mathrm{mg} \mathrm{kg}^{-1}$ $\mathrm{K}$ using $\mathrm{K}_{2} \mathrm{HPO}_{4}$. All nutrients except nitrogen were provided in a way that does not limit plant growth.
Black oat (Avena strigosa Schreb) was used as a plant test due to cultivation period (between June and August 2018) and its regrowth capacity, allowing to study more than one cut (Figure 1).

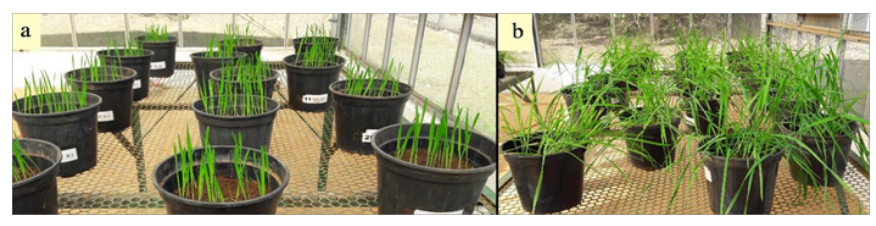

Figure I Overview of pots in greenhouse for residual effect evaluation: black oat (Avena strigosa Schreb) at 6 days (a) and 21 days after sowing (b).

We sowed thirty-three black oat seeds per pot. Soil moisture was maintained at $70 \%$ of water retention capacity (periodic weighing and water replacement).

The experiment had duration of 83 days and three aerial plants cuts were performed. The first cut was made at 34 days after sowing; the second occurred 29 days after the first, and the third cut was made 20 days after the second.

After the third cut, the roots were separated from the soil, washed to remove soil particles. All plant material was dried at $50^{\circ} \mathrm{C}$ in a forced circulation oven and masses were annotated for subsequent calculation of extracted N. Shoot and root samples were milled $(0.250$ $\mathrm{mm}$ mesh) and analyzed on the $\mathrm{CN}$ elemental analyzer.

From the dry mass and $\mathrm{N}$ concentration in plant tissue results, $\mathrm{N}$ content in plants was calculated.

Statistical analysis of the results was performed through analysis of variance (ANOVA) at $95 \%$ probability and comparison of means by $\mathrm{t}$-test $(\mathrm{p}<0.05)$. Statistical analysis was made using SISVAR software version $5.6 .^{20}$

\section{Results \& Discussion}

Ammonium, nitrate, and ammonium + nitrate $(\mathrm{N}$ inorganic) concentrations of the soil in initial conditions (0-15 cm layer) were presented in Figure 2.

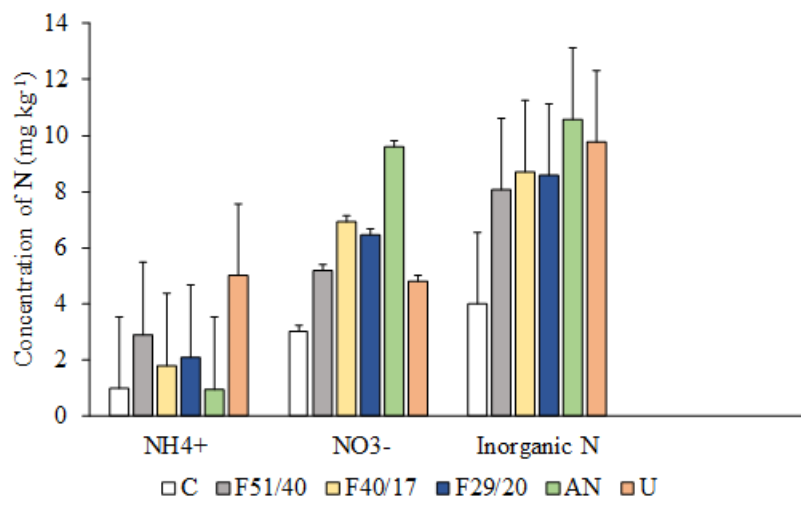

Figure 2 Ammonium $\left(\mathrm{NH}_{4}^{+}\right)$, nitrate $\left(\mathrm{NO}_{3}{ }^{-}\right)$and ammonium + nitrate $(\mathrm{N}$ inorganic) in soils that received application of nitrogen fertilizers (ammonium nitrate - AN; urea - $U$; and biochar-based fertilizers $-\mathrm{F}_{51 / 10}, \mathrm{~F}_{40 / 17}$, and $\mathrm{F}_{29 / 20}$ ) and in control soil (C). Vertical bars represent the minimum significant difference by the $5 \%$ t-test.

$\mathrm{NH}_{4}^{+}$concentration was higher using urea in comparison to $\mathrm{F}_{40 / 17}$, $\mathrm{F}_{29 / 20}$, ammonium nitrate and control treatments. Only urea differed from the control, which shows that there was no residual effect of the other nitrogen sources tested when considered initial $\mathrm{NH}_{4}^{+}$soil. 
The residual effect was better evidenced when $\mathrm{NO}_{3}{ }^{-}$concentrations were compared. All treatments, except urea, presented higher concentration in relation to the control. Ammonium nitrate presented higher contents $\left(9,61 \mathrm{mg} \mathrm{kg}^{-1}\right)$, followed by $\mathrm{F}_{40 / 17}, \mathrm{~F}_{29 / 20}$, and $\mathrm{F}_{51 / 10}$ formulations, with contents of $\mathrm{NO}_{3}^{-}$between 5.18 and $6.91 \mathrm{mg} \mathrm{kg}^{-1}$. The potential of biochar-based fertilizers has been attested by previous research evaluating water solubility and soil $\mathrm{N}$ release, where they were slower release compared to urea and ammonium sulfate. ${ }^{6}$ Thus, higher concentrations of inorganic $\mathrm{N}$ were expected in the soils that received the biochar-based fertilizers, which did not occur (Figure 2).

It is important to explain that the $\mathrm{N}$ recovery by corn crop was $12 \%$ higher for treatments with biochar-based fertilizers compared to urea, and that there was up to $21 \%$ gain in grain yield. ${ }^{6}$ In this sense, similar concentrations of soil $\mathrm{N}$ would be a result of the differentiated process of nutrient absorption by plants. Despite the few differences, soil $\mathrm{N}$ levels indicated the possibility of differential $\mathrm{N}$ supply to plants, which was better understood from the results of dry mass and tissue $\mathrm{N}$ contents.

Evaluating shoot dry mass (Figure 3), the treatment that provided the highest mass production was $\mathrm{F}_{40 / 17}$, and $\mathrm{F}_{29 / 20}$. The root compartment represented around $15 \%$ of total dry mass-produced by the plant and smaller differences were verified between the treatments. However, all fertilizer treatments provided higher root dry mass compared to the control.

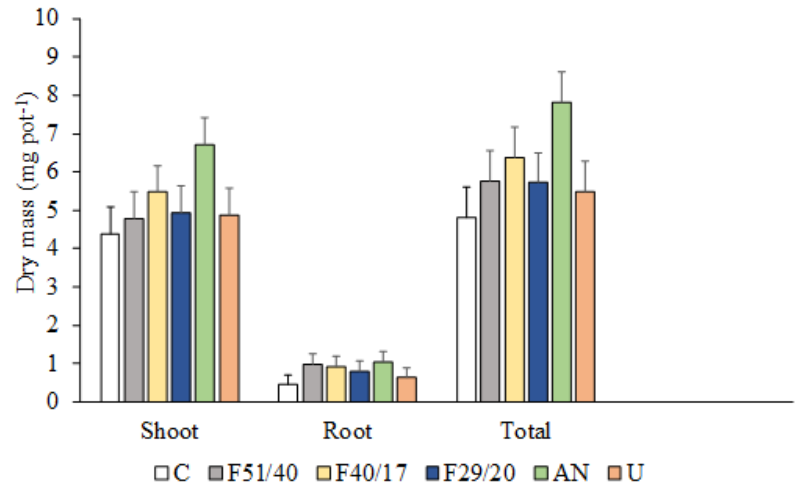

Figure 3 Black oat (Avena strigosa Schreb) dry mass of shoot and root in the treatments with nitrogen application (ammonium nitrate - $\mathrm{AN}$; urea -U; and biochar-based fertilizers - $\mathrm{F}_{51 / 10}, \mathrm{~F}_{40 / 17}$, and $\mathrm{F}_{29 / 20}$ ) and in control $(\mathrm{C})$. Vertical bars represent the minimum significant difference by the $5 \% \mathrm{t}$-test.

Considering dry mass produced in three cuts of the black oat shoot and the root system quantified at the end of 83 days of plant growth urea treatment did not differ from control, and nitrate ammonium treatment resulted on highest dry mass-amount. Biochar formulations occupied intermediate position.

Performing the composition with the results obtained by Puga et al. ${ }^{6}$ in the field experiment, it was ammonium nitrate that provided the lowest values for plant $\mathrm{N}$ recovery and yield, explaining the largest dry mass of black oats (Figure 3 ). The results of $\mathrm{N}$ extracted by plants confirm the greatest residual effect of ammonium nitrate (Figure 4).

As expected, $\mathrm{N}$ extracted by plants decreases with the sequence of cuts. Ammonium nitrate treatment presented higher $\mathrm{N}$ extraction from the soil in the first and second cuts of the black oat shoots. In these first and second cuts the formulated $\mathrm{F}_{40 / 17}$ and $\mathrm{F}_{51 / 10}$ presented differences in relation to the control, while the treatments $\mathrm{F}_{29 / 20}$ and urea were similar to the control in terms of $\mathrm{N}$ extracted.
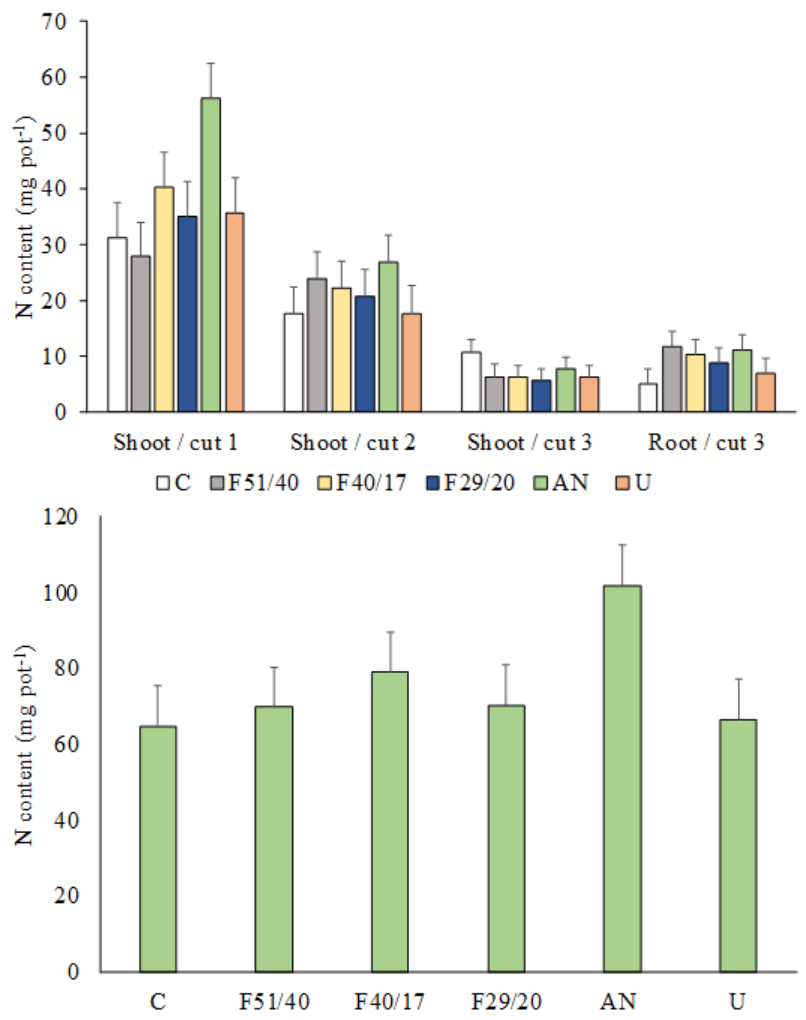

Figure 4 Nitrogen content in three consecutive cuts of black oat (Avena strigosa Schreb) shoot and in the root after third cut (a); and total nitrogen content in these plants (b) as a response to the residual effect of nitrogen fertilizers application (ammonium nitrate - AN; urea - U; and biochar-based fertilizers - $F_{51 / 10}, F_{40 / 17}$, and $F_{29 / 20}$ ), besides the control $(C)$. Vertical bars represent the minimum significant difference by the $5 \%$ t-test.

In the third cut of the shoot, the situation reversed. The $\mathrm{N}$ extracted by the control plants exceeded the values observed in the other treatments, which is explained by the exhaustion of $\mathrm{N}$ supply in the previous cuts when treatments with residual fertilizer provided higher dry mass yields. For the root system, the magnitude of extracted $\mathrm{N}$ compared to the total followed the same pattern observed for dry mass, as well as for treatments.

Nitric fertilizers generally have higher $\mathrm{N}$ losses from soil leaching, ${ }^{21}$ but here this does not appear to have occurred. Dalmolin et al. ${ }^{22}$ also found reduced $\mathrm{N}$ losses from leaching when ammonium nitrate was used compared to urea. In this case, the authors attributed this difference to the more intense denitrification process when the nitrogen source was ammonium nitrate, since there is no need for previous transformation of amidic $\mathrm{N}$ into ammonium and then nitrate. In the present research, however, this does not explain the performance of ammonium nitrate, since $\mathrm{N}$ was not excessively lost by denitrification. ${ }^{6}$

Ammonia volatilization from fertilizers partially explains the better residual effect of ammonium nitrate, in addition to the recovery of $\mathrm{N}$ by corn plants in the field. Ammonia volatilization reached $10-15 \%$ of total $\mathrm{N}$ applied via urea and fertilizers formulated with biochar, while in the case of ammonium nitrate the loss was zero. ${ }^{6}$

The greater residual effect of $\mathrm{F}_{40 / 17}$ compared to urea (Figure $4 \mathrm{~b}$ ) cannot, however, be attributed to the differential loss of ammonia in 
the field stage, because this biochar-based fertilizer has exceeded the urea in ammonia loss from volatilization. ${ }^{6}$

Considering the differences in corn grain yield and $\mathrm{N}$ recovery in the field in favor of biochar-based fertilizers, as well as the higher ammonia losses from these fertilizers compared to urea, ${ }^{6}$ the factor which allows the greatest residual effect observed is the slower $\mathrm{N}$ release in the system, corroborating the results of fertilizer development. ${ }^{6}$

\section{Conclusion}

Biochar-based nitrogen fertilizer formulated with urea has a longer residual effect compared to the exclusive application of urea and this effect is related to the slow $\mathrm{N}$ release, which demonstrates the potential of this technology in the formulation of enhanced-efficiency $\mathrm{N}$ fertilizers.

\section{Acknowledgements}

The authors are grateful for the financial support from São Paulo Research Foundation (FAPESP; Grant number 2017/02886-7).

\section{Conflicts of interests}

Authors declare no conflict of interest exists.

\section{References}

1. Malavolta E. Fertilization ABC. São Paulo: Ceres, 1979;292.

2. Cantarella H, Novais RF. Nitrogen. Soil fertility. Sociedade Brasileira de Ciência do Solo. 2007:375-470.

3. Zhang X, Davidson EA, Mauzerall DL, et al. Managing nitrogen for sustainable development. Nature. 2015;528:51-59.

4. Smil V. Nitrogen cycle and world food production. World Agriculture, Paris. 2011;2:9-12.

5. Ferguson RB. Groundwater quality and nitrogen use efficiency in nebraska's central platte river valley. J Environ Qual. 2015; 44(2):449459.

6. Puga AP, Queiroz MCA, Ligo MAV, et al. Nitrogen availability and ammonia volatilization in biochar-based fertilizers. Agron Soil Sci Arch. 2019.

7. Qian L, Chen M, Chen B. Competitive adsorption of cadmium and aluminum onto fresh and oxidized biochars during aging processes. Journal of Soil and Sediments. 2015;15:1130-1138.

8. Steiner C, Glaser B, Geraldes Teixeira W, et al. Nitrogen retention and plant uptake on a highly weathered central amazonian ferralsol amended with compost and charcoal. Journal of Plant Nutrition and Soil Science. 2008;171:893-899.
9. Lehmann J, Joseph S. Biochar for environmental management: science and technology. London: Earthscan. 2009;416.

10. European Biochar Foundation. European biochar certificate guidelines for a sustainable production of biochar: version 8.2E of 19th April 2019 Arbaz, Switzerland: EBC. 2013.

11. Santos F, Torn MS, Bird JA. Biological degradation of pyrogenic organic matter in temperate forest soils. Soil Biology and Biochemistry. 2012;51:115-124.

12. Abdelhafez AA, Li J, Abbas MHH. Feasibility of biochar manufactured from organic wastes on the stabilization of heavy metals in a metal smelter contamined soil. Chemosphere. 2014;117:66-71.

13. Ahmad M, Rajapaksha AU, Lim JE, et al. Biochar as a sorbent for contaminant management in soil and water: a review. Chemosphere. 2014;99:19-33.

14. http://www.mme.gov.br/web/guest/publicacoes-e-indicadores/balancoenergetico-nacional

15. Joseph S, Graber ER, Chia C, et al. Shifting paradigms: development of high-efficiency biochar fertilizers based on nano-structures and soluble components. Carbon Management. 2013;4:323-343.

16. Guimarães RD, Padilha FJ, Cedano J, et al. Residual effect of biochar and saw dust on carbon and total nitrogen contents in Yellow Latosol in Amazonia. Revista Virtual Química, Niterói. 2017;9:1944-1956.

17. Puga AP, Grutzmacher P, Cerri CEP, et al. Biochar-based nitrogen fertilizers: greenhouse gas emissions, use efficiency, and maize yield in tropical soils. Sci Total Environ. 2020.

18. Harbridge J. Determination of ammonia (salicylate) in $2 \mathrm{M} \mathrm{KCl}$ soil extracts by flow injection analysis (high throughput). Loveland, CO: Lachat Instruments, 2007;16.

19. Harbridge J. Determination of nitrate in $2 \mathrm{M} \mathrm{KCl}$ soil extracts by flow injection analysis. Loveland, CO: Lachat Instruments, 17 p. (QuikChem Method 12-107-04-1-J). 2007.

20. Ferreira DF. Sisvar: variance analysis system for balanced data. Lavras: UFLA, 1998;19.

21. Cantarella H, Mattos D, Quaggio JA, et al. Fruit yield of Valencia sweet orange fertilized with different $\mathrm{N}$ sources and the loss of applied N. Nutr Cycl Agroecosys. 2003;67:215-223.

22. Dal Molin SJ, Ernani PR, Soldatelli P, et al. Leaching and recovering of nitrogen following $\mathrm{n}$ fertilizers application to thesoil in a laboratory study. Commun Soil Sci Plan Anal. 2018;49:1099-1106. 